\title{
Inhibitory activity of Iranian plant extracts on growth and biofilm formation by Pseudomonas aeruginosa
}

\author{
Shahla Mansouri ${ }^{1 \star}$, Amin Safa ${ }^{2}$, Sasan Gholamhoseinian Najar ${ }^{3}$ and Ahmad Gholamhoseinian Najar ${ }^{4}$ \\ ${ }^{1}$ Department of Microbiology, and Research Center for Infectious Disease and Tropical Medicine .Medical School, \\ Kerman University of Medical Sciences, Kerman Iran. \\ ${ }^{2}$ Islamic Azad University, Young Researchers Club, Kerman Branch, Kerman Iran. \\ ${ }^{3}$ Microbiology Department, Islamic Azad University, Kerman Branch. \\ ${ }^{4}$ Department of Biochemistry and Physiology Research Center, Kerman University of Medical Sciences, Kerman, Iran. \\ Email: smansouri@kmu.ac.ir
}

Received 5 October 2012; Received revised form 15 February 2013; Acceptance 11 March 2013

\begin{abstract}
Aims: Pseudomonas aeruginosa is a drug resistance opportunistic bacterium. Biofilm formation is key factor for survival of $P$. aeruginosa in various environments. Polysaccharides may be involved in biofilm formation. The purpose of this study was to evaluate antimicrobial and anti-biofilm activities of seven plant extracts with known alpha-glucosidase inhibitory activities on different strains of $P$. aeruginosa.

Methodology and results: Plants were extracted with methanol by the maceration method. Antimicrobial activities were determined by agar dilution and by growth yield as measured by $\mathrm{OD}_{560 \mathrm{~nm}}$ of the Luria Bertani broth (LB) culture with or without extracts. In agar dilution method, extracts of Quercus infectoria inhibited the growth of all, while Myrtus communis extract inhibited the growth of 3 out of 8 bacterial strains with minimum inhibitory concentration (MIC) of 1000 $\mu \mathrm{g} / \mathrm{mL}$. All extracts significantly $(p \leq 0.003)$ reduced growth rate of the bacteria in comparison with the control without extracts in LB broth at sub-MIC concentrations $(500 \mu \mathrm{g} / \mathrm{mL})$. All plant extracts significantly $(p \leq 0.003)$ reduced biofilm formation compared to the controls. Glycyrrhiza glabra and $Q$. infectoria had the highest anti-biofilm activities. No correlation between the alpha-glucosidase inhibitory activity with growth or the intensity of biofilm formation was found.

Conclusion, significance and impact of study: Extracts of $Q$. infectoria and $M$. communis had the most antimicrobial, while $Q$. infectoria and G. glabra had the highest anti-biofilm activities. All plant extracts had anti-biofilm activities with marginal effect on growth, suggesting that the mechanisms of these activities are unrelated to static or cidal effects. Further work to understand the relation between antimicrobial and biofilm formation is needed for development of new means to fight the infectious caused by this bacterium in future.
\end{abstract}

Keywords: antimicrobial resistance, biofilm formation, Pseudomonas aeruginosa, Quercus infectoria, Myrtus communis, Glycyrrhiza glabra

\section{INTRODUCTION}

$P$. aeruginosa is an opportunistic pathogen widely distributed in the environment and had a versatile metabolic activity. This non- fermenting Gram negative rod is responsible for about $10 \%$ of all hospital acquired infections (Aloush et al., 2006; Enoch et al., 2007). Infections are opportunistic in nature and ranged from those associated with ventilator, catheter, burn and wound, to pulmonary infections in cystic fibrosis patients and keratitis in contact lens wearers (Lee et al., 2003; Choy et al., 2008). In recent years the emergence of multiple drug resistance $P$. aeruginosa became a major challenge in the treatment of corresponding infections (Lee et al., 2003; Choy et al., 2008). Clinically, drug resistance bacteria are responsible for increased cost, length of hospital stay and mortality (Poole, 2005). Innate resistance to antibacterial agents, acquisition of resistance genes by horizontal gene transfer, modification or inactivation and target alteration of drugs, low permeability or increased efflux systems and grow in a specific growth state like biofilm are important mechanisms involved in bacterial resistance. The factors that are contributed to resistance in biofilm forming bacteria includes the slow growth rate, decreased diffusion of antimicrobials and accumulation of enzymes that are involved in the resistance (Hogan and Kolter, 2002; Høiby et al., 2010). Completely formed (mature biofilm) in $P$. aeruginosa is surrounded by an exopolysaccharide matrix (Vasseur et al., 2005) and 
many adhesions such as flagella and fimbrial and non fimbrial adhesins are glycosylated (Power and Jennings, 2003). Quorum Sensing (QS) or bacterial cell to cell communication regulates the production of many virulence factors including biofilm formation in $P$. aeruginosa (Adonizio et al., 2008; Karatuna and Yagci, 2010).

Many compounds with antibacterial activity are being made and some of them are on clinical trials (Freire-Moran et al., 2011). However for treatment of important drug resistant pathogens, there is always a need for synthesis or to discover new antibacterial agents. Recently the inhibitory effect of different plant extracts on anti-adherence activity or other virulence factor production in bacteria have been reported (Andoğan et al., 2002; Adonizio et al., 2008; Islam et al., 2008; Kumar et al., 2010).

Complication with the use of antibacterial agents in the treatment of infections encouraged us to investigate seven plant extracts for their antibacterial and anti biofilm activities. Due to the importance of polysaccharide in the development of biofilm and their existence in the cell adhesion, this study was initiated to test the plants with known inhibitory effects on alpha-glucosidase activities (Table 1) on different strains of $P$. aeruginosa .

Table 1: Characteristics of plant materials used.

\begin{tabular}{|c|c|c|c|}
\hline Plant name & Plant family & $\begin{array}{l}\text { Used } \\
\text { parts }\end{array}$ & $\alpha$-glucosidase* \\
\hline $\begin{array}{l}\text { Glycyrrhiza } \\
\text { glabra }\end{array}$ & Fabaceae & $\begin{array}{l}\text { Aerial } \\
\text { parts }\end{array}$ & $41 \pm 3$ \\
\hline $\begin{array}{l}\text { Myrtus } \\
\text { communis }\end{array}$ & Myrtaceae & Leaves & $97 \pm 3$ \\
\hline $\begin{array}{l}\text { Punica } \\
\text { granatum }\end{array}$ & Lythraceae & $\begin{array}{l}\text { Fruit } \\
\text { hull }\end{array}$ & $93 \pm 1$ \\
\hline $\begin{array}{l}\text { Quercus } \\
\text { infectoria }\end{array}$ & Fagaceae & Galls & $98 \pm 2$ \\
\hline $\begin{array}{l}\text { Rosa } \\
\text { damasscens }\end{array}$ & Rosaceae & Floret & $98 \pm 1$ \\
\hline $\begin{array}{l}\text { Tecurium } \\
\text { polium }\end{array}$ & Lamiaceae & $\begin{array}{l}\text { Aerial } \\
\text { parts }\end{array}$ & $7 \pm 0.3$ \\
\hline $\begin{array}{l}\text { Zataria } \\
\text { multiflora }\end{array}$ & Lamiaceae & $\begin{array}{l}\text { Aerial } \\
\text { parts }\end{array}$ & 0.0 \\
\hline
\end{tabular}

${ }^{\star}$ The enzyme inhibitory activity of the plant methanol extracts on $\alpha$-galactosidse was tested using $100 \mu \mathrm{g}$ of extract and the results were presented as percent activity of the extracts in comparison with the controls (Gholamhoseinian et al., 2008).

\section{MATERIALS AND METHODS}

\section{Bacterial strains}

The following $P$. aeruginosa strains were used in this study: $P$. aeruginosa ATCC 27853 , and KOAS (harboring genes for extended spectrum $\beta$-lactamases) were obtained from Pasteur Institute of Iran, wild type strain PAO1 (MH 873), PDO300 (an alginate hyper producer due to inactivation of mucA gene) and mucoid strains (MS $50 / 35$, isolated from sputum of a patients with cystic fibrosis) were a gift from Professor Neils Høiby
(Copenhagen, Denmark). Three clinical isolates (PK60 from urinary tract infection and PK112 and PK116 from burn wounds of hospitalized patients in Kerman, Iran) were also included in the study. These isolates were identified to be different bacterial strains using random amplified polymorphic DNA analysis (unpublished results), and were included in the study because of their high biofilm activities (Norouzi et al., 2010).

Seven plant extracts with known anti a-glucosidase activities, were obtained from the Herbal Medicines Research Center, Faculty of Pharmacology, Kerman University of Medical Sciences, Iran. The methanol extracts of the plants (Table 1) were prepared by maceration method (Gholamhoseinian et al., 2008). The extracts were kept at $-70{ }^{\circ} \mathrm{C}$, before use. Extracts were dissolved in dimethyl sulfoxide (DMSO; Darmstadt, Germany) to obtain final concentrations of 100 to 1000 $\mu \mathrm{g} / \mathrm{mL}$ before use. The solvent concentration did not exceed $1 \%$ of final concentration.

\section{Effect of plant extracts on the growth of different strains of $P$. aeruginosa}

The effect of different plant extracts on growth inhibition of the tested bacteria was evaluated by two methods. In agar dilution method final concentrations of each crude extract (100 to $1000 \mu \mathrm{g} / \mathrm{mL}$ ) was added to sterile Mueller Hinton agar at $55^{\circ} \mathrm{C}$ and were poured in the plates (diameter of $10 \mathrm{~cm}$ ). The bacterial suspensions were adjusted to 0.5 MacFarland standards and were spot inoculated on the plate using hand inoculators (MAST England). The plates were incubated at $35^{\circ} \mathrm{C}$ overnight, and were examined for the absence of growth or type of colonies if the growth was not completely inhibited (Clinical and Laboratory Standards Institute, 2009). In the second method decrease in the turbidity of Luria Bertani (LB) broth in comparison with the growth in the absence of the extracts was determined (Rios et al., 1988). Sub-MIC concentrations of the extracts obtained by the agar dilution method for the active extracts (Quercus infectoria and Myrtus communis) were used in this experiment. Briefly starter cultures were prepared by inoculating the LB medium with a few colonies from an overnight medium incubated in a shaker incubator (120 rpm) for $24 \mathrm{~h}$. This starter culture $(1 \mathrm{~mL})$ was used to inoculate the fresh medium $(24 \mathrm{~mL})$, containing $500 \mu \mathrm{g} / \mathrm{mL}$ of the extracts. The cultures were incubated as mentioned earlier. $\mathrm{OD}_{560 \mathrm{~nm}}$ (as an index for growth) of culture was recorded after $24 \mathrm{~h}$. The $O D_{560 \mathrm{~nm}}$ of the medium in the absence of plant extracts were used as the control.

\section{Static biofilm assay}

Biofilm formation was measured as described by O'Toole and Kolter (O'Toole and Kolter, 1998). Overnight cultures of each bacterial strain were diluted to an $\mathrm{OD}_{600 \mathrm{~nm}}$ equal to 0.1 in fresh LB broth. In order to avoid biofilm inhibition in response to antimicrobial activities sub-MIC concentrations $(500 \mu \mathrm{g} / \mathrm{mL})$ of the extracts was tested in the biofilm assay. Crude plant extracts were added to the 
culture medium in the final concentrations of $500 \mu \mathrm{g} / \mathrm{mL}$. Culture aliquots $(100 \mu \mathrm{L})$ were added into the wells of sterile 96-well polystyrene microtiter plate (Falcon, USA) and incubated for $24 \mathrm{~h}$ at $30^{\circ} \mathrm{C}$. After three times wash with water, biofilm formation was visualized by staining with $0.1 \%$ crystal violet in water fallowed by three times rinse with water. Biofilm formation in the presence or absence of the extracts was visualized at $\mathrm{OD}_{595 \mathrm{~nm}}$ after addition of $200 \mu \mathrm{L}$ of $95 \%$ ethanol.

\section{Statistical analysis}

Dependent sample t-test was used to compare the antimicrobial and biofilm formation in presence or absence of the extracts. All the assays were repeated three times. Data were expressed as mean \pm standard deviation (SD), and $P$ value $\leq 0.05$ was considered to be statistically significant.

\section{RESULTS AND DISCUSSION}

\section{Antimicrobial resistance in agar and broth medium}

From different plant extracts tested only Quercus infectoria and Myrtus communis had growth inhibitory activity in the agar dilution method. $Q$. infectoria inhibited the growth of all the bacterial strains with an MIC of 1000 $\mu \mathrm{g} / \mathrm{mL}$. M. communis inhibited the growth of strains ATCC 27853, PK60 and PK112 strains at this concentration. The growth of other bacterial strains was no inhibited up to the concentration of $1000 \mu \mathrm{g} / \mathrm{mL}$ of the extracts. The strain MS50/35 had the mucoid appearance in presence of all extracts except the extracts of Quercus infectoria and Myrtus communis at different concentrations (Table 2). Other strains showed some type of variation in growth, producing variant colonies with different texture, morphology or pigmentation, the colonies were either small, round, flat, swarming and were dry, sticky, mucoid and rough in presence of different extracts. However the extracts of Glycyrrhiza glabra were an exception, and had no visible growth inhibitory activity for bacterial strains even at the concentration of $1000 \mu \mathrm{g} / \mathrm{mL}$. Growth in presence of Punica granatum results in highly pigmented colonies which were more colored than the colonies produced by the strains in the absence of the extracts. For summary the colonial morphology change of the bacterial strains with final concentration of $500 \mu \mathrm{g} / \mathrm{mL}$ is presented in Table 2.

Inhibitory activity of the plant extracts on growth in the LB medium for each strain is presented in Table 3 . The $\mathrm{OD}_{560 \mathrm{~nm}}$ of the bacterial strain without the extract was used as the growth control. Growth of all the bacterial strains in the presence of extracts resulted in the lower $\mathrm{OD}_{560 \mathrm{~nm}}$ compared to the growth of the control in the absence of the extracts $(p \leq 0.003)$ (Table 3$)$. The most active extracts were Zataria multiflora, Tecurium polium, Rosa damasscens and $P$. granatum $(p \geq 0.001)$. G. glabra had the lowest antibacterial activity compared to the other extracts $(p \geq 0.001)$ in liquid medium.

\section{Biofilm formation}

Intensity of the biofilm produced was significantly reduced in presence of all the extracts compared to the control strain grown in the absence of the extracts $(p \geq 0.003)$. The most active plant extracts inhibiting biofilm formations were G. glabra, Q. infectoria followed by Z. multiflora, and $M$. communis (Table 4). DMSO at the concentration applied in the medium was tested and showed no inhibitory effect on the growth or biofilm formation by the extracts.

\section{DISCUSSION}

Unrestricted use of antibacterial agents and bacterial strategies to produce various virulence factors such as those associated with quorum sensing systems (QS) are important causes of treatment failure in patients infected with drug resistance $P$. aeruginosa. QS system regulates the production of many virulence factors, as well as resistance to antibacterial agents mediated by the efflux pumps (Schweizer, 2003). Expressions of many virulence factor genes vary from strain to strain and are affected by the environmental conditions (Schulert et al., 2003). This study used seven plant extracts against 8 different strains of $P$. aeruginosa to determine their antimicrobial and anti biofilm activities. The result showed low antibacterial activity in the plant extracts tested and the only two active extracts had an MIC of $\geq 1000 \mu \mathrm{g} / \mathrm{mL}$, which is quite high. At lower concentrations $(100,250$ and $500 \mu \mathrm{g} / \mathrm{mL})$ the extracts did not inhibits the growth; however production of variant colonies on solid medium were observed. These variant colonies were not similar for different strains or extracts and affected the size, texture or pigmentations (Table 2). It was interesting that many extract had a better activity in inhibiting biofilm formation such as G. glabra, and $Q$. infectoria while Rosa damasscens only reduced pigmentation of the bacterial strains on solid media. A significant decrease in the production of pyoverdin in the plant extracts inhibiting biofilm formation is also reported by Adonizio et al., 2008. They did not observed significant change in cell growth corresponding to pyoverdin production which is in agreement with our findings. Deizel et al. described the small colony variant (S variants) of $P$. aeruginosa in response to environmental conditions (Deziel et al., 2001). The S variants were rough, hyperpiliated, defective in chemotaxis, hydrophobic and able to produce higher amount of pyocyanin, pyoverdin and a higher intensity to form biofims (Deziel et al., 2001). Change in the morphology of $P$. aeruginosa and production of deformed cells when grown in the presence of the Cratoxylum cochinchinense (Guttiferae) is also reported (Boonnak et al., 2009). Increase in pyocyanin production was also observed with the extracts of Manilkara zapota (Sapotaceae) and Ocimum sanctum (Lamiaceae) (Kumar et al., 2010). These morphological changes which are associated with a mechanism known as phase variation could be an adaptation to the change in environmental condition and helps the bacteria to survive (Deziel et al., 2001). Extracts of $Q$. infectoria and 
Mal. J. Microbiol. Vol.9(2) 2013, pp. 176-183

Table 2: Appearance of variant colony morphology of different strains of $P$. aeruginosa grown in presence of $500 \mu \mathrm{g} / \mathrm{mL}$ of methanolic plant extracts on solid medium.

\begin{tabular}{|c|c|c|c|c|c|c|c|c|}
\hline \multirow{2}{*}{ Bacterial strains } & \multirow{2}{*}{$\begin{array}{l}\text { Control, no } \\
\text { plant extract }\end{array}$} & \multicolumn{7}{|c|}{ Plants used } \\
\hline & & $\begin{array}{l}\text { Glycyrrhiza } \\
\text { glabra }\end{array}$ & $\begin{array}{c}\text { Myrtus } \\
\text { communis }\end{array}$ & $\begin{array}{l}\text { Punica } \\
\text { granatum }\end{array}$ & $\begin{array}{l}\text { Quercus } \\
\text { infectoria }\end{array}$ & $\begin{array}{c}\text { Rosa } \\
\text { damasscens }\end{array}$ & $\begin{array}{l}\text { Tecurium } \\
\text { polium }\end{array}$ & $\begin{array}{l}\text { Zataria } \\
\text { multiflora }\end{array}$ \\
\hline ATCC 27853 & WT; LF; Gr & DS; LF ; CR & DR; SR; Db & $\mathrm{D} ; \mathrm{SR} ; \mathrm{Db}$ & $\mathrm{D} ; \mathrm{RS}$; CR & DS; SR; CR & $\mathrm{D} ; \mathrm{SF} ; \mathrm{Db}$ & DS; SF; CR \\
\hline KOAS & WT; LF;CR & Ws; LS;CR & DR; SR; Db & $\mathrm{D} ; \mathrm{SR} ; \mathrm{CR}$ & DS; SR;CR & DS; SR; CR & $\mathrm{D} ; \mathrm{SF} ; \mathrm{Y}$ & DS; SR; CR \\
\hline PDO300 & WT; LF; Gr & WT; LS;CR & DR; SR; Db & WT; SF; Gr & D; SR;CR & Mu ; SR;CR & D; SF; Y & WT; SF; CR \\
\hline MH 873 (PAO1) & $\mathrm{Mu} ; \mathrm{LF} ; \mathrm{Gr}$ & WT; LS; Gr & DR; SF; Gr & Mu; SF; Db & D; SR;CR & DR; SR;CR & $\mathrm{D} ; \mathrm{SF} ; \mathrm{Gr}$ & DR; SF;CR \\
\hline MS 50/35 & $\mathrm{Mu} ; \mathrm{LF} ; \mathrm{Gr}$ & Mu; LF;CR & DR; SF; Db & Mu; LF; Db & WT; SR;CR & $\mathrm{Mu} ; \mathrm{LF} ; \mathrm{CR}$ & Mu; SF; Db & Mu; SR; CR \\
\hline Pk 60 & WT; LF; Gr & WT; LF;CR & DR; SR; Gr & $\mathrm{D} ; \mathrm{SR} ; \mathrm{Db}$ & D; SR;CR & DR; SR;CR & D; SF; Db & DR; SR; CR \\
\hline PK 112 & WT; LF;Gr & WT; LS; CR & DR; SR; Gr & D; SF; Db & $\mathrm{D} ; \mathrm{SR} ; \mathrm{CR}$ & $\mathrm{DR} ; \mathrm{SF} ; \mathrm{Gr}$ & D; SF; CR & DR; SF; CR \\
\hline PK 116 & WT; LF;Gr & WT; LF; CR & DR; SR; Gr & D; SF; Db & Dr ; SR;CR & DR; SF; CR & $\mathrm{D} ; \mathrm{SF} ; \mathrm{Gr}$ & DR; SR; CR \\
\hline
\end{tabular}

Texture of colonies- D: dry; DR: dry rough; DS: dry sticky; WT: wet; Ws: wet sticky; Mu: mucoid

Size of colonies- SR: small round; SF: small flat; LF: large flat; LS: large swarming colonies.

Pigmentation- CR: cream color; Gr: green color; Db: dark blue color; Y: yellow color 
Mal. J. Microbiol. Vol.9(2) 2013, pp. 176-183

Table 3: Decrease in $\mathrm{OD}_{560 \mathrm{~nm}}$ (antimicrobial activities) of different strains of $P$. aeruginosa grown on LB broth in presence or absence (control) of plant extracts at concentration of $500 \mu \mathrm{g} / \mathrm{mL}$ after $24 \mathrm{~h}$ of incubation at $35^{\circ} \mathrm{C}$.

\begin{tabular}{|c|c|c|c|c|c|c|c|c|}
\hline \multirow{2}{*}{ Bacterial strains } & \multirow{2}{*}{$\begin{array}{l}\text { Control, no } \\
\text { plant extract }\end{array}$} & \multicolumn{7}{|c|}{ Plants used } \\
\hline & & $\begin{array}{l}\text { Glycyrrhiza } \\
\text { glabra }\end{array}$ & $\begin{array}{c}\text { Myrtus } \\
\text { communis }\end{array}$ & $\begin{array}{c}\text { Punica } \\
\text { granatum }\end{array}$ & $\begin{array}{l}\text { Quercus } \\
\text { infectoria }\end{array}$ & $\begin{array}{c}\text { Rosa } \\
\text { damasscens }\end{array}$ & $\begin{array}{l}\text { Tecurium } \\
\text { polium }\end{array}$ & $\begin{array}{c}\text { Zataria } \\
\text { multiflora }\end{array}$ \\
\hline ATCC 27853 & 1.08 & 0.65 & 0.32 & 0.26 & 0.49 & 0.26 & 0.21 & 0.39 \\
\hline KOAS & 0.62 & 0.51 & 0.39 & 0.51 & 0.53 & 0.45 & 0.57 & 0.38 \\
\hline PDO300 & 0.91 & 0.44 & 0.32 & 0.18 & 0.29 & 0.17 & 0.15 & 0.18 \\
\hline MH 873 (PAO1) & 0.80 & 0.52 & 0.42 & 0.25 & 0.36 & 0.25 & 0.28 & 0.30 \\
\hline MS 50/35 & 0.92 & 0.53 & 0.32 & 0.25 & 0.35 & 0.20 & 0.14 & 0.15 \\
\hline Pk 60 & 0.92 & 0.53 & 0.32 & 0.25 & 0.35 & 0.25 & 0.14 & 0.15 \\
\hline PK 112 & 0.80 & 0.52 & 0.42 & 0.25 & 0.30 & 0.25 & 0.28 & 0.30 \\
\hline PK 116 & 0.91 & 0.44 & 0.32 & 0.15 & 0.29 & 0.17 & 0.15 & 0.15 \\
\hline Mean* & $0.87 \pm 0.13$ & $0.51 \pm 0.06$ & $0.36 \pm 0.05$ & $0.26 \pm 0.1$ & $0.37 \pm 0.08$ & $0.25 \pm 0.08$ & $0.24 \pm 0.14$ & $0.25 \pm 0.1$ \\
\hline
\end{tabular}

Values in the columns represent mean $\mathrm{OD}_{560 \mathrm{~nm}}$ of triplicate samples.

${ }^{*}$ The mean of data in each column is presented in the last row as the mean \pm standard deviation. 
Mal. J. Microbiol. Vol.9(2) 2013, pp. 176-183

Table 4: Biofilm formation by different strains of $P$. aeruginosa at concentration of $500 \mu \mathrm{g} / \mathrm{mL}$.

\begin{tabular}{|c|c|c|c|c|c|c|c|c|}
\hline \multirow{2}{*}{ Bacterial strains } & \multirow{2}{*}{$\begin{array}{l}\text { Control, no } \\
\text { plant extract }\end{array}$} & \multicolumn{7}{|c|}{ Plants used } \\
\hline & & $\begin{array}{l}\text { Glycyrrhiza } \\
\text { glabra }\end{array}$ & $\begin{array}{c}\text { Myrtus } \\
\text { communis }\end{array}$ & $\begin{array}{l}\text { Punica } \\
\text { granatum }\end{array}$ & $\begin{array}{l}\text { Quercus } \\
\text { infectoria }\end{array}$ & $\begin{array}{c}\text { Rosa } \\
\text { damasscens }\end{array}$ & $\begin{array}{l}\text { Tecurium } \\
\text { polium }\end{array}$ & $\begin{array}{c}\text { Zataria } \\
\text { multiflora }\end{array}$ \\
\hline ATCC 27853 & 0.15 & 0.08 & 0.08 & 0.08 & 0.07 & 0.07 & 0.11 & 0.09 \\
\hline KOAS & 0.25 & 0.12 & 0.12 & 0.12 & 0.08 & 0.11 & 0.17 & 0.09 \\
\hline PDO300 & 0.37 & 0.20 & 0.32 & 0.37 & 0.15 & 0.36 & 0.36 & 0.36 \\
\hline MH 873 (PAO1) & 0.32 & 0.07 & 0.08 & 0.07 & 0.08 & 0.07 & 0.10 & 0.08 \\
\hline MS 50/35 & 0.26 & 0.14 & 0.19 & 0.15 & 0.18 & 0.11 & 0.24 & 0.11 \\
\hline PK 60 & 0.35 & 0.26 & 0.36 & 0.29 & 0.32 & 0.21 & 0.36 & 0.21 \\
\hline PK 112 & 0.29 & 0.09 & 0.16 & 0.37 & 0.07 & 0.36 & 0.21 & 0.19 \\
\hline PK 116 & 0.32 & 0.10 & 0.17 & 0.37 & 0.09 & 0.36 & 0.24 & 0.21 \\
\hline Mean \pm SD & $0.29 \pm 0.07$ & $0.13 \pm 0.06$ & $0.18 \pm 0.10$ & $0.23 \pm 0.13$ & $0.13 \pm 0.08$ & $0.20 \pm 0.13$ & $0.22 \pm 0.10$ & $0.17 \pm 0.09$ \\
\hline
\end{tabular}

Biofilm production is expressed as the $\mathrm{OD}_{595 \mathrm{~nm}}$ after incubation with crystal violet. Values in the columns represent mean $\mathrm{OD}_{595 \mathrm{~nm}}$ of triplicate samples.

*The mean of data in each column is presented in the last row as the mean \pm standard deviation. 
M. communis were the most active extract able to inhibit the growth of all or some of the bacteria strains with MIC of $\geq 1000 \mu \mathrm{g} / \mathrm{mL}$. Limsuwan et al. reported high activity of $Q$. infectoria extract (MIC $250 \mu \mathrm{g} / \mathrm{mL}$ ) for $P$. aeruginosa strain NPRCM1201 (Limsuwan et al., 2009). In all other reports a broad spectrum of activity is reported for both of these plant extracts against important pathogens including $P$. aeruginosa but the reported MIC range for $P$. aeruginosa is either similar or higher than our findings (Mansouri, 2001; Shahidi Bonjar, 2003; Basri and Fan, 2005; Voravuthikunchai, 2008). Since the MIC of the $Q$. infectoria and $M$. communis extracts for all, or some strains were $1000 \mu \mathrm{g} / \mathrm{mL}$ respectively the growth inhibitory activity in liquid medium was tested at a lower concentration than MIC (sub-MIC) for all the extracts. In LB liquid medium at this concentration all the extracts reduced the growth yield of the bacterial strains, as was compared to the optical density of the culture in the absence of plant extracts $(p \leq 0.003)$. These phenomena could be due to the nature of the extracts since the polarity, lipolytic activity and diffusion of plant extracts in the agar medium could affect the outcome of the assay (Rios, 1988). This observation may explain the discrepancies in the results obtained with agar dilution compared to liquid medium. Different efflux pumps are identified in $P$. aeruginosa , which may affect the genes involved in the biosynthesis of QS system. Reduced growth rate in response to the efflux of toxic compounds linked to the production of QS system in $P$. aeruginosa has been reported (Aendekerk, 2005). All the plant extracts used in this study significantly reduced the mean intensity of biofilm formation by the bacterial strains. The inhibitory activity was unique for different bacterial strains, emphasizing an unknown activity of the components of the crude extracts for different bacterial strains. The inhibitory activity of the extract on the bacterial growth at the concentration employed could not affect the outcome of biofilm formation assay; because G. glabra with the lowest antimicrobial activity in agar or broth dilution method inhibited the biofilm formation by bacterial strains and the inhibitory activity was comparable to that of $Q$. infectoria. In a similar study with plant extracts Adonizio et al. suggested that the biofilm formation as other factors involved in QS mechanisms are unrelated to the static or cidal effects of the extracts (Adonizio et al., 2008). No correlation between the anti alpha-glucosidase inhibitory activity and antibacterial activity or biofilm formation of the plant extracts were found in the present study. However other factors such as matching the concentration of the extract used for biofilm formation and that of the anti alpha-glucosidase activity is necessary before any suggestions.

\section{CONCLUSION}

In conclusion this study highlights the antimicrobial and anti biofilm activity of some Iranian traditional plants. Many other factors may be involved in the virulence of $P$. aeruginosa. It will be worthwhile to test these plants against other virulence factors related to the QS system. Purification of active principal of the extracts provides an insight into the usage of plant material with natural origin which may be less toxic to use as an alternative agents for the treatment of bacterial infections. Crude extracts can also be used as topical agents in the treatment of wound or burns associated with bacterial infections that forms biofilms especially against multi drug resistant strains of $P$. aeruginosa in burn patients or those with the urinary tract catheter.

\section{ACKNOWLEDGMENTS}

We are greatly indebted to the Young Researchers Club, Islamic Azad University, Kerman Branch and Research Center, Kerman University of Medical Sciences for the financial support.

\section{REFERENCES}

Adonizio, A., Kong, K. F. and Mathee, K. (2008). Inhibition of quorum sensing-controlled virulence factor production in Pseudomonas aeruginosa by South Florida plant extracts. Antimicrobal Agents and Chemotherapy 52(1), 198-203.

Aendekerk, S., Diggle, S. P., Song, Z., Høiby, N., Cornelis, P., Williams P. and Ćamara, M. (2005). The MexGHI-OpmD multidrug efflux pump controls growth, antibiotic susceptibility and virulence in Pseudomonas aeruginosa via 4-quinolone-dependent cell-to-cell communication. Microbiology 151(4), 1113-1125.

Aloush, V., Navon-Venezia, S., Seigman-Igra Y., Cabili S. and Carmeli Y. (2006). Multidrug-resistant Pseudomonas aeruginosa: Risk factors and clinical impact. Antimicrobial Agents and Chemotherapy 50(1), 43-48.

Andoğan, B. C., Baydar, H., Kaya, S., Demirci, M. and Öbbaşar, D. (2002). Antimicrobial activity and chemical composition of some essential oils. Archieves of Pharmacal Research 25(6), 860-864.

Basri, D. F. and Fan, S. H. (2005). The potential of aqueous and acetone extracts of galls of Quercus infectoria as antibacterial agents. Indian Journal of Pharmacology 37(1), 26-29.

Boonnak, N., Karalai, C., Chantrapromma, S., Ponglimanont, C., Fun, H. K., Knjana-Opas, A, Chantrapromma, K. and Kato, S. (2009). AntiPseudomonas aeruginosa xanthones from the resin and green fruits of Cratoxylum cochinchinense. Tetrahedron 65(15), 3003-3013.

Choy, M. H., Stapleton, F., Willcox, M. D. P. and Zhu, H. (2008). Comparison of virulence factors in Pseudomonas aeruginosa strains isolated from contact lens- and non-contact lens-related keratitis. Journal of Medical Microbiology 57(12), 1539-1546.

Clinical and Laboratory Standards Institute (2009). Methods for dilution antimicrobial susceptibility tests for bacteria that grow aerobically. Approved 
standards. $8^{\text {th }}$ edn. M7-A8.Clinical and Laboratory Standards Institute, Wayne, PA.

Deziel, E., Comeau, Y. and Villemur, R. (2001). Initiation of biofilm formation by Pseudomonas aeruginosa 57RP correlates with emergence of hyperpiliated and highly adherent phenotypic variants deficient in swimming, swarming, and twitching motilities. Journal of Bacteriology 183(4), 1195-1204.

Enoch, D. A., Birkett, C. I. and Ludlam, H. A. (2007). Non-fermentative Gram-negative bacteria. International Journal Antimicrobial Agents 29(3), S3341.

Freire-Moran, L., Aronsson, B., Manz, C., Gysson, I. C., So, A. D., Monnet, D. L. and ECDC-EMA working group (2011). Critical shortage of new antibiotics in development against multidrug-resistant bacteriaTime to react is now. Drug Resistance Updates 14(2), 118-124.

Gholamhoseinian, A., Falah, H., Sharififar, F. and Mirtajadini, S. (2008). The inhibitory effect of some Iranian plants extracts on the alpha-glucosidase. Iranian Journal Basic Medical Sciences 1(37), 1-9.

Hogan, D. and Kolter, R. (2002). Why are bacteria refractory to antimicrobials? Current Opinion in Microbiology 5(5), 85-90.

Høiby, N., Bjarnsholt, T., Givskov, M., Molin, S. and Ciofu, O. (2010). Antibiotic resistance of bacterial biofilms. International Journal of Antimicrobial Agents 35(4), 322-332.

Islam, B., Khan, S. N., Haque, I., Alam, M., Mushfiq, M. and Khan, A. U. (2008). Novel anti-adherence activity of mulberry leaves: Inhibition of Streptococcus mutans biofilm by 1-deoxynojirimycin isolated from Morus alba. Journal of Antimicrobial Chemotherapy 62(4), 751-757.

Karatuna, O. and Yagci, A. (2010). Analysis of quorum sensing dependent virulence factor production and its relationship with antimicrobial susceptibility in Pseudomonas aeruginosa respiratory isolates. Clinical Microbiology and Infection 16(12), 17701775.

Kumar, R., Chhibber, S. and Harjai K. (2010). Evaluation of anti-quorum sensing activity of edible plants and fruits through inhibition of n-acylhomoserine lactone system in Chromobacterium violaceum and Pseudomonas aeruginosa. Chemotherapy 56, 333-339.

Lee, E. J., Cowell, B. A., Evans, D. J. and Fleiszig, S. M. (2003). Contribution of ExsA-regulated factors to corneal infection by cytotoxic and invasive Pseudomonas aeruginosa in a murine scarification model. Investigative Ophthalmology \& Visual Science 44(9), 3892-3898.

Limsuwan, S., Subhadhirasakul, S. and Voravuthikunchai, S. P. (2009). Medicinal plants with significant activity against important pathogenic bacteria. Pharmaceutical Biology 47(8), 683-689.

Mansouri, S., Foroumadi, A., Ghaneie, T. and Najar, A. G. (2001). Antibacterial activity of the crude extracts and fractionated constituents of Myrtus communis. Pharmaceutical Biology 39 (5), 399-401.

Norouzi, F., Mansouri, S., Moradi, M. and Razavi, M. (2010). Comparison of cell surface hydrophobicity and biofilm formation among ESBL-and non-ESBLproducing Pseudomonas aeruginosa clinical isolates. African Journal of Microbiology Research 4(11), 1143-1147.

O'Toole G. A. and Kolter, R. (1998). Flagellar and twitching motility are necessary for Pseudomonas aeruginosa biofilm development. Molecular Microbiology 30(2), 295-304.

Poole, K. (2005). Efflux-mediated antimicrobial resistance. Journal Antimicrobial Chemotherapy 56(1), 20-51.

Power P. M. and Jennings, M. P. (2003). The genetics of glycosylation in Gram-negative bacteria. FEMS Microbiology Letters 218(2), 211-222.

Rios, J. L., Recio, M. C. and Villar, A. (1988). Screening methods for natural products with antimicrobial activity: A review of the literature. Journal of Ethnopharmacology 23(2-3), 127-149.

Schulert, G. S., Feltman, H., Rabin, S. D. P., Martin, C. G., Battle, S. E., Rello, J and Hauser, A. H. (2003). Secretion of the toxin ExoU is a marker for highly virulent Pseudomonas aeruginosa isolates obtained from patients with hospital-acquired pneumonia. Journal of Infectious Disease 188(11), 1695-1706.

Schweizer, H. P. (2003). Efflux as a mechanism of resistance to antimicrobials in Pseudomonas aeruginosa and related bacteria: unanswered questions. Genetics and Molecular Research 2(1), 48-62.

Shahidi Bonjar, G. H., Nik, A. K., Heydari, M. R., Gasemzadeh, M. H., Farrokhi, R., Moein, S. M. R., Mansouri, S. and Foroumadi, A. (2003). Antipseudomona and anti-bacilli activity of some medicinal plants of Iran. DARU Journal of Pharmaceutical Science 11(4), 157-163

Vasseur, P., Vallet-Gely, I., Soscia, C., Genin, S. and Filloux, A. (2005). The pel genes of the Pseudomonas aeruginosa PAK strain are involved at early and late stages of biofilm formation. Microbiology 151(3), 985-997.

Voravuthikunchai, S. P., Chusri, S. and Suwalak S. (2008). Quercus infectoria. Oliv. Pharmaceutical Biology 46(6), 367-372. 